\title{
De rerum natura: On the Nature of Existence and the Existence of Nature in the mundo maya and Beyond
}

\author{
Harri Kettunen
}

\begin{abstract}
:
In Mayan languages, as in many other Indigenous languages around the world, there is no traditional word for 'nature.' The lack of such terminology stems from the fact that the division between the human realm and the environment we live in has not been (historically or culturally) as separated as it is in the modern world. However, while there are no traditional words for 'nature' in Mayan languages, some of the languages use descriptive terms or neologisms that are often translated as 'nature' in dictionaries and other linguistic sources. The focus of this article is to understand the concept of nature in the Maya worldview based primarily on linguistic sources.
\end{abstract}

Keywords: Maya, concept of 'nature' in Indigenous languages, ontology of nature

\section{Resumen:}

DE RERUM NATURA: SOBRE LA NATURALEZA DE LA EXISTENCIA Y LA EXISTENCIA DE LA NATURALEZA EN EL MUNDO MAYA Y MÁS ALLÁ

En los idiomas mayas, al igual que en muchas otras lenguas indígenas de todo el mundo, no existe una palabra tradicional para la "naturaleza". La falta de este término se debe al hecho de que en los tiempos antiguos no se observaba histórica o culturalmente una división tan visible entre el ámbito humano y el medio ambiente como en la actualidad. Sin embargo, aunque en los idiomas mayas no existen palabras que definan exactamente la "naturaleza", algunos de los idiomas utilizan términos descriptivos o neologismos que en los diccionarios y otras fuentes lingüisticas a menudo se traducen como la "naturaleza". El enfoque de este artículo es comprender el concepto de la naturaleza en la cosmovisión maya principalmente en base a las fuentes lingüisticas.

Palabras clave: maya, concepto de 'naturaleza' en lenguas indígenas, ontología de la naturaleza

Harri Kettunen - University of Helsinki, email: harri.kettunen@helsinki.fi,

(D) https://orcid.org/0000-0002-3004-5678 


\section{Introduction}

In Mayan languages, as in many other Indigenous languages around the world, there is no traditional word for 'nature.' The lack of such terminology stems from the fact that the division between human beings and the environment we live in - and the division between populated and unpopulated areas - has not been (historically or culturally) as separated as it is in the modern world ${ }^{1}$. However, while there are no traditional words for 'nature' in Mayan languages, some of the languages use descriptive terms or neologisms that are often translated as 'nature' (or related terms) in dictionaries and other linguistic sources. These include K'iche' uwach uleew ("face of the earth") for 'nature' and Jakaltek stxotx'alq'inal for 'biotope' (from stx'otx'al, 'earth of' and q'inal, 'life'). The main focus of this article is to understand the concept of nature in the Maya worldview based primarily on linguistic sources. Besides the Maya area, the article explores the concept of nature - and its personified and gender-specific manifestations - in other cultures and languages around the world for comparative purposes. The title of the article invokes Lucretius's didactic poem De rerum natura as well as McTaggart's The Nature of Existence and seeks to see whether Western concepts can be used to describe non-Western ideas, concepts, and beliefs.

\section{The linguistics of nature in the Maya area}

While a few Mayan languages have constructed terms (mostly neologisms; see below) that are translated as 'nature' (naturaleza in Spanish) in dictionaries, most Mayan languages operate with descriptive terms, such as "face of the earth," or use the dichotomy town vs. forest (see below). In Mayan languages there are a number of terms for 'earth' that are used when forming the concept "face of the earth." One of them, $k a b$, can be reconstructed all the way back to Proto-Mayan (Kaufman 2003:414, 2017:95), although the term is restricted to Yukatekan languages today as a reference to 'earth' (Yukatek kàab 'land, world' [Bricker et al. 1998:118], Itza' kab 'world' [only in derived words, compounds, or fixed phrases] [Hofling and Tesucún 1997:332], and Mopan kab 'world' [Hofling 2011:227]), while in other languages it has either gone through a semantic shift - or it only appears in restricted compounds - as in Tzotzil chob 'milpa' (Delgaty 1964:14), and various terms for 'earthquake,' including Tzeltal liki chab (Kaufman 2003:414), K'iche' kabraqän (ALMG 2004a:63), and the reconstructed Greater Q'anjobalan ${ }^{\star} k i x$ kab (Kaufman 2003:414) and Greater Mamean ${ }^{\star} k a b(-l a)$ junab (Kaufman 2003:414).

Another term for 'earth, land,' common in Lowland Mayan languages ( $\mathrm{Yu}-$ katekan and Greater Tzeltalan), along with Chuj and Tojolabal, is Greater Lowland ${ }^{*}$ lu?m (Kaufman 2003:384) and its descendant forms: Yukatek lúPum (Bricker et al. 1998:175), Itza' and Mopan luPum (Hofling and Tesucún 1997:426; Hofling 
2011:295), Lacandon ruPm (Hofling 2014), Chorti' rum (Hull 2016:351), Chol, Tzeltal, and Tzotzil lum (Aulie and Aulie 1978:75; Slocum 1953:37; Hurley and Ruíz 1986:79), as well as Chuj and Tojolabal luPum (ALMG 2003e:60; Jackson and Supple 1952:40). Furthermore, K'iche'an languages have a term for 'earth, land', deriving from Greater K'iche'an *uleew (Kaufman 2003:416), with descendant terms, such as Uspantek uleew (Vicente Méndez 2007:283), K'iche' ulew uleew (ALMG 2004a:130), Tzutujil and Sakapultek uleew (Cruz Ajcac et al. 2014; ALMG 2001c:98), and Kaqchikel and Sipakapa ulew (Ruyán Canú et al. 1991:228; ALMG 2001d:98).

Besides the aforementioned terms, Eastern Mayan languages - along with the languages in the Huehuetenango diffusion zone belonging to the Q'anjobalan branch - have terms for 'earth' that derive from Eastern Mayan * ch'o?ch' (Kaufman 2003:414). These include tx'otx' in Mam (ALMG 2003a:146, 2010:515), Tektitek (ALMG 2003d:75), and Awakatek (ALMG 2001a:88), choch' in Q'eqchi' (ALMG 2004b:75), and (in the Q'anjobalan branch) tx'otx' in Q'anjobal (ALMG 2003b:143) and Jakaltek (Ramírez Pérez 1996:281), and tx'ootx' in Akatek (Andrés et al. 1996:187). Lastly, Poqomam (ALMG 2003c:14; McArthur and McArthur 1995:1) and Poqomchi' (Dobbels 2003:30) have ak'al for 'earth'.

In Central Mayan languages, there is a shared concept of "face of the earth" that can be translated as 'soil,' 'earth', or 'world' (and 'nature' as we will see later) depending on the language and context. These include Chol panumil (Becerra 1937:25) or pañimil (Aulie and Aulie 1978:91-92), from pan-lum-il, "above / on.top. of / front / surface / forehead-earth" (Hopkins et al. 2011:173-174), Tzotzil balumil, as well as banamil, banomil, and banumil, depending on the dialect (Hurley and Ruíz 1986:18), from ba-lum-il, "above/on.top.of-earth," Tzeltal balumilal bahlumilal (Slocum 1953:6; Kaufman 2003:417), Mopan yokol-kab (Ulrich \& Ulrich 1976:253; Hofling 2011:479) and Yucatec 'okol kaab (Bricker at al. 1998:16), Ixil vatz tx’ava? (Kaufman 2003:417), K’iche' (ALMG 2004a:135), Sakapultek ${ }^{2}$ (Vásquez Aceituno 2007:434), and Uspantek (Vicente Méndez 2007:289) wach uleew, Tźutujil rwachPuleep ruwachPuleew (Pérez Mendoza and Hernández Mendoza 1996:372; Kaufman 2003:418), Kaqchikel ruwachPulew (Ruyán Canú et al. 1991:207), Poqomam naah ak'al and wach ak'al (ALMG 2003c:108), Q'anjobal sat tx'otx' (ALMG 2003b:125), and Mam twitz tx'otx' (Kaufman 2003:418). Mam (ALMG 2003a:137) has also twitz q'ijlal for 'world, life, nature.'

In addition, besides being translated as 'world,' the K'iche' term uwach uleew is translated as 'nature' (Sp. naturaleza) in the K'iche' dictionary with neologisms (ALMG 2003f:52). Similarly, Sipakapa (ALMG 2001d:79) has rwoch uleew for 'ecosystem, nature' (as in Ri qchak are' ri xtqchjaj ri rwoch uleew or "Our task is to care for the ecosystem"). The aforementioned K'iche' dictionary (ALMG 2003f:4041) has also terms for 'flora' (urexal uwachulew [3SE-green-ABSTR-3SE-face-earth] or "the green of the face of the earth") and 'fauna' (rawajil uwachulew or "the animals of the face of the earth"). Likewise, Jakaltek (ALMG 2001f) has neologisms 
related to the concept of 'nature.' These include stx'otx'alq'inal for 'biotope' (from stx'otxal, 'earth of' and q'inal, 'life'), as well as ehobal tx'otx' for 'biosphere' (from ehoj [root of the verb 'to be'], -bal [locative suffix], and tx'otx', 'earth'). Terms for larger concepts include Achi term kajuleew for universe (ALMG 2001g:136), from kaaj 'sky' and uleew 'earth,' as well as Poqomchi' taxaaj ak'al for 'world, universe, sky, and earth' (Dobbels 2003:654), i.e., literally "sky-earth," reminiscent of Finnish maailma ('world, earth, universe'), literally "earth-air."

Besides these, Popol Vuh (Christenson 2003:48) uses merismus where two terms or concepts form a new concept. These include "sky-[and]-earth" as "creation as a whole," "mountain-[and]-valley" as "the face of the earth as a whole" and "deer[and]-birds" as "all wild animals" versus "dogs-[and]-turkeys" as "all domesticated animals." The last two pairs seem to reflect the opposition of wilderness and human habitation. Furthermore, the juyub' taq'aj, or "mountains+valleys" parallels Chuj witz 'ak'lik, or literally "mountain+plains/valleys," referring to the earth in general and glossed as "The Earth Lord, the spirit of the mountain" by Hopkins (2012:6, 383). The lines in Popol Vuh (Christenson 2004:15) are as follows:

$\begin{array}{ll}\text { Ronojel kaj, } & \text { All sky, } \\ \text { Ulew. } & \text { Earth. } \\ & \text { "sky-earth" = "creation as a whole" }\end{array}$
Juyub' Mountains, (lines 240-241)
Taq'aj. Valleys.
"mountain-valley" = "the face of the earth as a whole"

Ri kiej, The deer, (lines 338-390)

Tz'ikin. Birds.

"deer-birds" = "all wild animals"

Ix chi k'ut, You now therefore,

(lines 746-749)

Xkixqati' chik," We will eat you now,

Xcha' ri ki tz'i, Said the their dogs,

Kak' chikech. Their turkeys to them.

"dogs-turkeys" = "all domesticated animals"

All in all, Mayan languages either lack a specific term for 'nature' or it is constructed by using semantically related terms. A dictionary search of 29 Mayan languages produced only a few direct translations of Spanish 'naturaleza' ('nature'). These include, besides the neologisms mentioned above, only one direct translation (gloss) of 'nature': Awakatek wisqiil (ALMG 2001a:101). Besides the terms mentioned above, Mayan languages make the difference between inhabited areas 
(such as a village) and the wilderness (usually a forest or 'montaña/monte, i.e., literally 'mountain, hill' but more commonly 'bush, wilderness'). These include Yukatek k'áax 'forest' vs. kàah 'town' (Bricker et al. 1998:120, 148), Lacandon k'áax 'forest' vs. kajar 'town' (Hofling 2014:205), Itza' kaax 'forest' vs. kaj 'town' (ALMG 2001b:37, 42; Hofling and Tesucún 1997:333, 387), and Mopan che'il 'wild, uncivilized' vs. kaj 'town' (Hofling 2011:151) in the Yukatekan branch; Chol tePel 'forest, jungle' (Hopkins et al. 2011:218), Chontal te?e? 'forest, jungle' (Keller and Luciano 1997:235), Chorti' ajkopot ' 'wild, of the forest' and nuk-te? ("large-tree") 'hills, forest in the mountains' (Hull 2016:35, 307), Tzeltal tePeltik 'forest' (Slocum 1953:75), and Tzotzil jabnaltik and mol tePtik 'forest, mountains', literally "old forest" (Hurley and Ruíz 1986:57, 84) ${ }^{4}$ in the Greater Tzeltalan languages; Chuj yax lu?um 'virgin forest, rain forest' (Hopkins 2012:408), literally "green-earth," and Akatek xol(aj) te?(laj) "in the forest" (Andrés et al. 1996:221) in the Greater Q'anjobalan languages; Mam and Tektitek tze? (ALMG 2003a, 2003d) and Awakatek tx'ok'been (ALMG 2001a:88) 'forest' in the Greater Mamean languages; K'iche' k'ichePlaj (ALMG 2004a:63), Achi k'achePlaaj (ALMG 2001 e:55), Kaqchikel k'ichelaj (ALMG 2011:53), Poqomam k'ichee? (ALMG 2003c:97), Poqomchi' chahn (Dobbels 2003:123), and Q'eqchi' ''iche' (Stoll 1896, Part 2; ALMG 2004b:113) 'forest, montaña' in the Greater K'iche'an languages, along with Wastek te Plom 'forest' (Larsen 1955:88).

The Mayan terms also reflect a more general Mesoamerican idea of uninhabited areas as 'forest,' 'wilderness,' or monte (i.e., 'wilderness, uncultivated land') as in Nahuatl cuauhtlah ( $k^{w}$ awtlah) and cuauhyoh ( $k^{w}$ awyoh) (Karttunen 1983:64), Amuzgo jndë (Stewart and Stewart 2000:72), Mixe (of San Juan Colorado) <cuhu> (kùùu) (Stark et al. 1986:11), Otomi (of San Andrés Cuexcontitlán) xanthi (//ănthỉ/) (Lastra de Suárez 1989:143), and Xinka kraw'a grawa (Rogers 2010:369, n.d.a:4, n.d.b.:17), to name a few. The semantics of nature-related terminology can also be geographically motivated. While the aforementioned terms refer either to the wilderness in general - or foresty areas in particular - terms in other languages reflect the surrounding environment in a different manner: e.g., in Seri (Komkaak), a language isolate in Sonora, Mexico (outside Mesoamerica proper), wilderness is associated with a desert, as in $<$ heecot $>$ (/Pk:kot/), which is glossed as "monte, vegetación [desert area]" in Moser and Marlett (1998:17) ${ }^{5}$.

\section{The concept of 'nature' in the European linguistic landscape}

As regards the terms for 'nature' in other languages around the world, the concepts and their etymologies are as varied as the languages. However, some interesting patterns that can be observed. Some are due to lexical borrowings, some attributable to linguistic areas (sprachbunds, diffusion areas), and some to common human concepts of the surrounding environment. Moreover, it is difficult to assess how culture affects people's ideas of nature - and how the terminology (or the lack 
of it) related to nature affects how the speakers of a given language perceive the natural environment around them. Evidently, each individual has a different relationship with nature ${ }^{6}$, but culture and society also affect it, and the terminology related to nature shapes how people perceive it and talk about it. The semantic field of the English word 'nature' includes terms such as natural, innate, raw, uncontrolled, wild, primitive, free, untouched, and uncultivated. However, when we look at the etymology of the word, a somewhat different semantic scope arises. The Latin term nāturra, from which the English term 'nature' derives from (along with more than half of the terms for 'nature' in all European languages), translates as birth, character, quality, essence, substance, element, disposition, inclination, temperament, the natural world, the universe, and male organ, all deriving from nātūrus, future active participle of nāscor gnāscor ("to be born"), and ultimately from Proto-Indo-European * ǵenh ${ }_{1}$ "beget a child, to give birth, be born" (Lewis and Short 1879:1189-1190; Mallory and Adams 2009:474; Streng 1933:481-482).

While the Germanic and Romance languages (along with Albanian, Irish, Scots Gaelic, Welsh, and Polish, as well as the non-Indo-European Basque and Maltese) have a Latin-based term for 'nature,' most Slavic languages derive their term from Proto-Slavic * roditi. Interestingly, however, the term is synonymous, or near- synonymous to the etymology of the term 'nature,' with the meaning "to give birth, bear (fruit)" - itself from Proto-Balto-Slavic *radei- or *radi-, a cognate with Latvian raditt, "to give birth to, to create" (Derksen 2008:437, 2015:177). Similarly, Lithuanian gamtà, 'nature, derives from Proto-Baltic *gim-, itself from Proto-Indo-European ${ }^{*} \mathrm{~g}^{\mathrm{w}} \mathrm{em}$-, with the meaning "to come," and also "to come out into the world," i.e., "to be born," and etymologically the same as the English verb 'to come,' and, e.g., Spanish venir (Mallory and Adams 2009:394-396). Semantically associated, although with a distinct etymology, is the Greek term for 'nature,' $\varphi v \dot{\sigma \eta}$

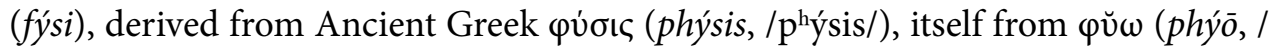
$\mathrm{p}^{\text {hý}}$ ://), "to grow," and ultimately from Proto-Indo-European ${ }^{*} \mathrm{~b}^{\mathrm{h}} \mathrm{uH}-$, "to appear, become, rise up," which also gave, e.g., the English word 'to be' and Spanish fui (and fue, fui-, fuer-, fues-).

Furthermore, in the Uralic languages, terms for 'nature' are semantically associated with the neighboring Indo-European languages. Hungarian has természet for 'nature', from terem, 'to produce' + nominalizing suffix -észet (Zaicz 2006:739740) while Finnish luonto ('nature, outside world, natural order, quality, property') derives from the verb luoda, 'to create, bring about' and 'shovel (snow)' (SSA3 1995:105, 108). Closely related languages have similar terms, such as Northern Sami luond $u^{7}$ (Álgu database 2021) and Estonian loodus (EKI ühendsõnastik 2020), derived (along with Finnish luonto) from Proto-Finnic *loodak ("to throw, to cast, to push away" and "create, make"), itself from Proto-Finno-Volgaic ${ }^{\star}$ lone- ("to throw, push away") (Âlgu database 2021; SSA2:105). Another related term is the Finnish ympäristö, or 'environment', from ympäri ('around'), a borrowing from Proto- 
Germanic *umbi ('around'), itself from Proto-Indo-European ${ }^{*} h_{2}$ entb ${ }^{\text {hi }}$ ('around, on both sides'), and ultimately from ${ }^{*} h_{2}$ ent-, or 'face' (SSA3 2000:491; Mallory and Adams 2009:289, 291). This is also the origin of Latin ambi- ('around, about, on each side of') and its derivatives, including English 'ambient.' Consequently, Finnish ympäristö and English 'ambient' come from the same source. Interestingly, these are also semantically related to English 'environment', from French en ('in') + viron ('a turn').

\section{On the personification and gender of nature}

Nature is also personified in many cultures around the world. "Mother Earth" and "Mother Nature" are widespread concepts with a myriad of artistic, linguistic, and mythological representations around the world and throughout human history. However, as artistic representations of "Mother Earth" predate written records and attested linguistic terms, it is not always easy to connect later cultural phenomena to earlier manifestations in material culture. In spite of this, archaic cultures have produced symbolic imagery with affinities to the later manifestations of the concept of "Mother Earth," as demonstrated by Marija Gimbutas (1991) and Nikos Chausidis (2012). According to Gimbutas (1991:228), "[f]rom the Upper Paleolithic, symbols appear representing the Goddess's fertility. She is portrayed as a naturalistic nude with hands placed on her enlarged belly, her pregnant form apparently likened to the fecundity of the seeded earth and all its creatures." Furthermore, Gimbutas (1991:230) adds that "[ $t]$ here is no doubt that the prehistoric veneration of Mother Earth survived intact up to the time of the worship of Demeter and Persephone in Greece, Ops Consiua in Rome, Nerthus in Germanic lands, Zemyna or Zemes Mate in the Baltic area, Mother Moist Earth in Slavic lands, and elsewhere. Her power was too ancient and deep to be altogether destroyed by succeeding patriarchal religions, including Christianity." Although neither Gimbutas nor Chausidis discuss Indigenous ideas of "Mother Nature" or "Mother Earth," the concept appears to be near-universal.

While there are male "earth gods" and female "sky gods," the idea of the nature being feminine is quite widespread. One of the well-known Indigenous American manifestations of "Mother Earth" is the Quechua Pachamama, from pacha ('earth, land, time, universe') and mama ('mother') (DQEQ 2005:294, 373, 375). Others include widespread Native North American concepts of "Mother Earth." According to the interviews carried out by Jostad et al. (1996:572) with members of nine Native North American groups (Blackfoot, Coeur d'Alene, Colville, Kalispel, Menominee, Nez Perce, Salish, Spokane, and Warm Springs), "[i]n the traditional context, the language used by those interviewed was completely gender-specific; Mother Earth is "she," the rivers are her blood, and we come from her womb of creation." However, although the fundamental concept surely exists, it is worth not- 
ing that none of the Indigenous languages of the peoples interviewed in Jostad et al. (1996) have gendered pronouns. While some, such as Okanagan (Colville-Okanagan), has gender suffixes and some, such as Blackfoot, has grammatical gender (although animate-inanimate, not sex-specific ${ }^{9}$ ), none of the languages mark pronouns with gender. Consequently, the interviews were probably carried out in English. However, this does not mean that the underlying concept of "Mother Nature" would not be present in the language, culture, and worldview of the said groups.

Furthermore, it is worth noting that the gender of the various terms for 'nature' in Indo-European languages is feminine: Sanskrit प्रकृति (prakŕti), Latin nātūra (along with descendant terms in, e.g., French, Italian, and Spanish), Slavic природа

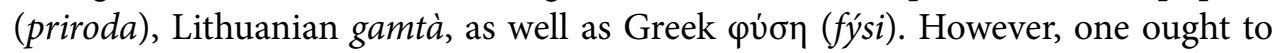
be careful when interpreting gender categories based solely on grammatical gender without understanding the underlying semantics of these terms.

Besides the examples provided by Gimbutas (1991:230) above (Demeter, Persephone, Ops, Nerthus, Žemyna ${ }^{10}$, Zemes Mate, and "Mother Moist Earth"), many other female deities in European mythology can be associated with the concept "Mother Earth." These include Jord Jörd Jörð, from Old Norse jorð, 'earth' (Icelandic jörð and Danish, Norwegian, and Swedish jord, cognates of English earth and Gothic NIR N [airpa], from Proto-Germanic *erpō and, ultimately, from Proto-Indo-European ${ }^{*} h_{1}$ er-, 'earth'), Fjorgyn, Frigg, and Freya, as well as Гaĩa (Gaĩa), $\Gamma \tilde{\eta}$ (Gê), Tellus, Terra, and Venus ${ }^{11}$ in the Greco-Roman tradition (Daly 2009:23, 33, 58; Lindow 2001:205-206; Orchard 1997: 44, 98), along with numerous other personifications of nature and earth in different cultures around the world.

\section{"Mother Earth" and the mother of the earth in the Andes}

After the Spanish conquest in the Andes, the image of the Virgin Mary was associated with Pachamama (Yetter 2017:2). Although there is some controversy as to the forms and extent of this syncretism (see below), the connection can be observed on many levels, including language, art, religion, and worldviews. The linguistic connection is manifested in the terms wirjunn (or wirjen) Pachamama (Harris 2000), a clear connection to the Virgin Mary. Artistic representations are epitomized in the anonymous Andean painting from 1720 titled "Virgen del Cerro" ("Virgin of the Hill," "Virgin of the Mountain," or "Virgin of the Mountain of Potosí" in English translations) ${ }^{12}$ which portrays the Virgin Mary within a mountain. The mountain itself represents Cerro Rico, the main source of silver of the Spanish Empire and the largest single source of silver in the history of mankind. Known also as the "mountain that eats men," due to the harsh conditions and treatment of the Indigenous miners (Ferry 1999; Izagirre 2019; Lane 2019), the Indigenous attitude towards Cerro Rico is rather mixed. The aforementioned painting shows the Virgin Mary merged with the mountain, exhibiting adits (entrances to the mines), trees, 
llamas, and Indigenous people, and surrounded by dignitaries and religious icons, and flanked by the Sun and the Moon. While the connection to the Indigenous past of the area is clear, the symbolism is almost entirely imported. Furthermore, although the connection between mountains and Virgins existed already in Spain (e.g., the Virgin of Montserrat), and this connection might have had an influence on the Andean tradition (Damian 1995; Duncan 1986), the fusion of the mountain and the Virgin Mary appears to be motivated by local ideology. For example, as far as I know, none of the images of the Virgin of Montserrat portray the Virgin merged with the mountain. Instead, the figure is always shown in front of it. Consequently, although the connection between the Virgin of Montserrat and the Virgin of the Mountain of Potosí seems obvious, there is no reason to suggest that these two are related (see also Nair 2007:211-212).

However, this does not mean that the Virgin Mary and Pachamama were not associated with each other. Derks and Heessels (2011:304-305) point out that right after the introduction of Catholicism in Bolivia, the Indigenous people of the area associated the Virgin Mary with Pachamama as protective and fertile mother figures. According to van Kessel (1992:1), both Pachamama and the Virgin Mary give and take care of life, watch over the fertility of the cattle, the crops of the farm, and secure the rains and the next agricultural cycle. In return, both ask for "payments" in the form of offerings: flowers, fruits, and seeds ${ }^{13}$.

On the other hand, as Salles-Reese (1997:38) observes, the "association with lust $[\ldots]$ renders impossible the Pachamama's syncretization with the Virgin Mary; unlike the Mother of Christ, the Indian deity is nor virginal, chaste, or pure." Consequently, according to Tola (2018:28), the assimilation of Pachamama into the Christian framework was rather complicated, as for the European missionaries, "Pachamama and the Andean women who revered it also evoked lust, lasciviousness and moral chaos." Furthermore, as Dean $(2010: 36,68,91)$ points out, while the earth or Pachamama is conceptually feminine, many distinct parts of the earth, such as individual stones (especially named ones), outcrops, and mountains, are often masculine while, e.g., caves, as places of origin or birth, are feminine. Moreover, according to Dean $(2010: 44,45,68)$, commonly, the wank'a (rocks that were perceived as "petrified owners of places, such as fields, valleys, and villages") were related to masculine issues associated with male semination, such as flood, drought, and warfare.

The relationship between people and Pachamama in the Andes was that of reciprocity. As Tola (2018:28) points out, "[w]hen treated with respect, the earth could respond with abundant harvests. Failure to pay proper attention to Pachamama, however, could lead to arid soils, illnesses and even death." Consequently, "[a] lthough capable of generating life, the pre-Hispanic Pachamama could hardly be described as a benevolent, all-giving mother" (Tola 2018:28). The association and partial fusion of Pachamama and the Virgin Mary is a prime example of European 
and Indigenous surface-level syncretism where the entities are not entirely fused but, instead, co-existing and - to some extent - complementary or even contradictory. Consequently, the nature of the relationship should be labeled as pericretic - to coin a term - rather than syncretic ${ }^{14}$.

To elaborate the relationship and circumstances further, Yetter (2017:3) points out that "[e]ven though these beliefs were syncretized with the model of the Virgin Mary, the Spanish male conquerors were blind to the Andean motives of the preservation of their own cultural ideologies." Consequently, as Vuola (2019:105) observes, "Pachamama does not merge into Mary. Rather, they co-exist and share common elements, but also have characteristics of their own." Furthermore, Tola (2018:28-29) notes that in Western modernity, the relationship between nature and society has been based on a rigid opposition in which the earth is a feminized setting for human endeavors, whereas, in the Andean ontology, the relationship is complementary and fluid.

\section{"Mother Earth" in the mundo maya}

As regards the concept of "Mother Earth" in the Maya area and Mayan languages, a dictionary search of 30 Mayan languages produced only one direct reference regarding the concept, i.e., Achi (ALMG 2001e:72) qachuu ulew, glossed as "madre tierra." Although references to "Mother Earth" do exist in the modern Mayan languages, the concept itself seems to be a modern development in the Maya area. Based on discussions with speakers ${ }^{15}$ of various Mayan languages in 2021, the concept was known but its historical depth contested. Nevertheless, eight out of ten people who took part in a survey ${ }^{16}$ carried out among speakers of six Mayan languages in Guatemala answered that they do use the concept of "Mother Earth" in reference to the earth. However, only one provided a term in a Mayan language for the concept. Furthermore, while many people who took part in the survey answered that the earth is feminine, many also replied that earth does not have gender - or it is composed of both genders. One answer was particularly revealing:

"In general, we refer to the earth as our mother, but there are also specific spaces or areas that can be masculine, such is the case of some mountains that are recognized as masculine and bear masculine names, but most of them are feminine. It is also important to mention that there are some places that are not defined by sex - it is only known that they are sacred and have names. [...] In our community, for example, in general it is Qatut Ak'al, but if we refer to the Volcán de Agua, we say the Yuuk' Jun Ajpú or Qatat Yuuk' Jun Ajpú - and Jun Ajpú in our thought and oral tradition is masculine, although it is still part of a whole." ${ }^{17}$

Yet, according to Héctor Aj Xol Chok (personal communication, 2021), the concept was all but unknown a few decades ago but has become more common - especially among the Maya who have worked in NGOs and studied in universi- 
ties. He also notes that the new concept ignores the concept of duality in the Maya thought.

Nonetheless, the concept does exist in the modern Maya parlance - and also in more traditional surroundings. According to Kerry Hull (personal communication, 2021), the Chorti' regularly refer to the earth as "Mother" - especially in ritual contexts. Furthermore, as there is no grammatical gender in Mayan languages, the gender shows up in explicit nominal references. Hull (2003: 146) notes that "gender association parallelism results from the common frame of reference of the sun and the earth, or as the Chorti' say today, "Padre Jesus" and "Madre Tierra."' In addition, Hull (2003:174) notes that "[ $t$ ] he earth, like all other 'good' beings in Chorti' mythology, have 'evil' counterparts. All the principal angels have Underworld counterparts who are responsible for causing illnesses. Even Jesus Christ has his evil equivalent in Chorti' thought." Furthermore, the femininity of the earth is obvious in the Chorti' planting rites, with references to Mother Earth and Our Mother [the Earth] (Kerry Hull, personal communication, 2021).

The concept is also used in Yucatan - although it is conspicuously absent in the Yucatec linguistic sources. However, the concept does exist in the ritual language of some elders today, as recorded in 2010 by Harald Thomaß (In Press) who documented the following phrase voiced by Don Antonio:

Tin k'ubik waay lu'um kaabile', para empezar y cerrar: in na' lu'um "Lo entrego aquí en la tierra, para empezar y cerrar: mi madre tierra" ("I give it here on earth, to start and close: my mother earth")

How traditional, common, or widespread the concept na' lu'um is, requires more research. Interestingly, however, it has found its way into modern phraseology and names of, e.g., organizations, businesses, and merchandise, including $\mathrm{Na}^{\prime} \mathrm{Lu} \mathrm{u}^{\prime} \mathrm{m}$ Cacao Institute (Belize), Koox Na'Lu’um Eco Hotel (Tecoh, Yucatán), Na' Lu’um Restaurant (Mérida, Yucatán), Instituto Ná Lu’ Um, (El Soberbio, Misiones, Argentina), Colectivo Na'lu’um - environmental and social community organization (Yucatán), Grupo Ecologista Na Luúm (Campeche), Ak na'lu’um educational website, Espacio Pachamama U Nai Na Luum cultural center, In na lu’um Facebook blog, Ná Lu’um Art, Na Lu'um Cosmética Nativa (Quintana Roo), Na'lu'um health and beauty products (Yucatán), Na' Lu'um artisanal soaps (Mexico City and Quintana Roo), Na Luum ecological products (Quintana Roo), Na'luum wood products (Yucatán), Lu'um Na' apartments and condos (Campeche), Artesanos $\mathrm{Na}^{\prime}$ Lu'um (Cancún, Quintana Roo), and The Swallows of Na' Lu'um song by Nicholas Gunn. Similarly, we have the "Mother Earth" concept appearing in Guatemala, including Asociación Tuut Ak'al Chib'aatz' (tuut ak'al for "mother earth" in Poqomchi').

Besides the earth itself, the Maya concepts of earth beings/deities (from the ancient Maya texts ${ }^{18}$ and iconography to modern Maya concepts) personify aspects 
of the earth - much the same way as in many other cultures around the world. Reflections of these ideas are found in concepts such as Mam or "grandfather" - with connections to earth and mountain spirits of great antiquity ${ }^{19}$. However, these beings have, more than often, other aspects and attributes - making it problematic to associate them with earth exclusively. For example, God N is associated with the aforementioned Mam but it also has other attributes that are not connected with terrestrial phenomena (Taube 1992:92-99). Another example is God D whose celestial association is widespread. However, he is also associated with the earth, especially during the Postclassic and Colonial eras - much the same way as Tönacätēcuhtli in the Aztec worldview. Similarly, the Central Mexican deities with connections to the earth, including the aforementioned Tönacàtēcuhtli, as well as Tlältēcuhtli, Tōnacācihuātl, Chicomecōàtl, and Cōàtlìcue, also possess other aspects beyond the earthly associations (Seler 1887:227, 234; Taube 1992:36-41). The fluidity of these beings makes their classification as mere earth deities problematic.

\section{Concluding remarks}

The terminology around the concept of nature is in constant motion in the languages and cultures around the world, and the Maya area and Mesoamerica are no exceptions. Although there are no traditional terms for 'nature' in many languages, new concepts based on changing perspectives of the world around us emerge in all languages. These include neologisms as well as semantic extensions of existing terms. Furthermore, besides the terminology itself, nature and earth are often personified in Indigenous cultures. However, although the idea of "Mother Earth" has recently gained currency in the Maya area, the concept is not autochthonous. Instead, it appears to be a borrowed concept - albeit falling into a fertile ground. Moreover, rather than being based on rigid oppositions, the Maya idea of the earth and the natural world surrounding us is complementary - rather than markedly either feminine or masculine.

\section{Notes}

1 The modern world (modern era, modernity) refers here to the socio-cultural values, attitudes, and norms, as well as the world system and historical era from roughly the 16th century onwards, characterized first by European hegemony and later by globalization, and associated with capitalism, technological progress, individualism, and urbanization (see, e.g., Braudel 1979; Goody 2004; and Wallerstein 2004).

2 Sakapultek has also kajulew, glossed as 'naturaleza' ('nature') in ALMG (2001c:38). The term does not, however, appear in Vásquez Aceituno 2007.

3 The Chorti' term k'opot is interesting, as there's a chance that this term reflects part of a name on the Terminal Classic Randel Stela of Sak Tz'i', written as AJ-YAX-k'o?-bo?-ta (Aj Yax K'obot?), or "He of the Green Forest."

4 Note also Tzotzil (Hurley and Ruíz 1986) chij as 'ram, lamb, sheep, deer' vs. te'tikal chij 'deer' (literally "forest deer") and chitom as 'pig' vs. te'tikal chitom as 'peccary' (jabali in Spanish in Hurley and 
Ruíz [1986:41] - a loanword from Arabic بَjejabaliyy, "of the mountains"). Similarly, there is a development in K'iche' where kej used to mean only 'deer' but refers to a 'horse' today, while a Nahua loanword masat (and, to a lesser extent, $k e j$ ) refers to a 'deer.' In the same way, ak' used to mean 'turkey' in K'iche' and now $a k^{\prime}$ or ti'j $a k^{\prime}$ ' is 'chicken,' while no's and qu'l means 'turkey'. These are typical semantic shifts in other Mayan languages as well - along with many other languages around the world. Of particular interest are the Old Tupi names for 'jaguar' and 'tapir.' According to Lemos Barbosa (1956:83, 385-386), in Old Tupi, the superlative particle, eté came to clarify confusion after the contact with European languages. Certain lexical items, especially specific domestic animals that were unknown to the Indigenous people of the area, were named after similar familiar entities, including: wine: kâ̂̃ ('cauin'); ox: tapiira ('tapir'); and dog: îaguara ('jaguar'). Subsequently, the native terms were augmented with the eté particle to produce kaû̃-eté for 'cauin'; tapiir-eté for 'tapir'; and îagûar-eté for 'jaguar,' or "onça legitima, grande." Still today in modern Guarani, jagua means 'dog' while jaguarete is 'jaguar.' However, 'tapir' is mborevi and 'ox' is guéi (an obvious loanword from Spanish).

5 Note also <heecto quiih> (/Pa:kto ki:P/) as "cazar (estar en el monte) [hunt]" and <heecot coom> (/Pa:kot ko:m/) "buscar visión [seek vision]" in Seri (Moser and Marlett 1998:17).

6 As demonstrated in the (linguistically ambiguous) movie line "this is not natural" in Irvine Welsh's Trainspotting (Welsh 1993), with a reference to outdoors in the Scottish nature.

7 The term understood as 'nature' is a modern concept in Sami languages, influenced by the Finnish term luonto. The primary meaning of the term is 'nature' or 'character' as is "human nature."

8 Although Pachamama is often translated as "Mother Earth," the concept is far more comprehensive, encompassing time along with space. Furthermore, as Yetter (2017:11) notes, "Pachamama [is] mother earth as well as the mother of earth."

9 Furthermore, as Kilarski (2007:334) points out, “[...] the principal differences between Algonquian and Indo-European gender, [...] involve the type of assignment criteria: in contrast to Algonquian, semantic criteria in Indo-European are usually weaker, being combined with formal ones (morphological or phonological). Furthermore, sex, rather than animacy, is the primary distinction, similarly to many other language families of the Old World, as well as, e.g., Northern Iroquoian among North American languages." However, it is also worth noting that the animate-inanimate contrast (rather than pure sex-based distinction) was also present in the Proto-Indo-European pronominal system.

10 Žemyna derives from the reconstructed name of the Proto-Indo-European earth goddess ${ }^{\star} \mathrm{D}^{\mathrm{h}} \mathrm{ég}^{\mathrm{h}} \overline{\mathrm{h}} \mathrm{m}$,

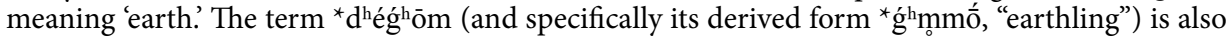
the source for Proto-Italic ${ }^{\star}$ hemō and Latin homō ("human being"), and its descendant terms: Italian uomo, French homme, and Spanish hombre, as well as Latin (etc.) humus ("earth, soil"), and English human (Mallory and Adams 1997:174, 2009:471).

11 As Mother Earth in Lucretius' De Rerum Natura (Fratantuono 2017:15-17).

12 There are two versions of the painting: one at the Casa Nacional de Moneda de Bolivia (The National Mint of Bolivia) in Potosí and the other at Museo Nacional de Arte, La Paz, Bolivia.

13 "[...] ambas - Pachamama y la Virgen - son las que dan y cuidan la vida y la salud de sus hijos y ambas piden en "pago" elementos idénticos que observamos en el culto que se les rinde. En el ambiente rural, ambas han de vigilar por la fertilidad del ganado, los cultivos de la chacra y la oportunidad de las lluvias. Ambas reciben las ofrendas de flores, frutas y semillas y ambas han de cuidarles y regenerarlas en el próximo ciclo agrícola" (van Kessel 1992:1). Note also an interesting recent Indigenous ritual that was performed in the Vatican, with a "dance resembling the 'pago a la tierra,' a traditional offering to Mother Earth" (see Mares 2019).

14 I.e., 'around or near,' rather than 'together' with "Cretans."

15 Dora Maritza García Patzán (Kaqchikel), Romelia Mo’ Isem (Poqomchi’), Héctor Aj Xol Chok (Q’eqchi'), and Crisanto Kumul Chan (Yucatec).

16 Carried out with the help of Romelia Mo' Isem in October 2021.

17 "De manera general nos referimos a la tierra como nuestra madre, pero igualmente hay espacios o áreas especificas que pueden ser masculinos tal es el caso de algunas montañas que son reconocidas como masculinos y llevan nombres masculinos, pero en su mayoria es femenino. Tambien es importante mencionar que hay algunos lugares que no se define si tiene sexo, solo se sabe que es sagrado y tiene un nombre. [...]. En fin en nuestra comunidad por ejemplo en su generalidad es 
Qatut Ak’al, pero si nos referimos al Volcán de Agua, le decimos la Yuuk' Jun Ajpú o Qatat Yuuk' Jun Ajpú, y Jun Ajpú en nuestro imaginario y tradicion oral es Masculino, aunque sigue siendo parte de un todo."

18 Epigraphic references to earth gods include the phrase kanal k'uh kabal k'uh, or "celestial gods, earthly gods" (e.g., Tikal Stela 31 and the "Vase of the Seven Gods" [K2796]).

19 Although references to earth as "mother" exist in the modern Maya worldview, I have yet to encounter any explicit references to female earth deities in a pre-Columbian Maya context.

\section{References cited:}

Abbreviations of dictionaries and other linguistic sources:

ALMG: Academia de las Lenguas Mayas de Guatemala ${ }^{1}$

DQEQ: Diccionario quechua-español-quechua

SSA: Suomen sanojen alkuperä: Etymologinen sanakirja 1-3

ALMG 2001a Tqan Qayool, Vocabulario Awakateko: Awakateko-Español, Español-Awakateko. Guatemala: Academia de Lenguas Mayas de Guatemala.

ALMG 2001b Jiilt'an Maya Itza, Vocabulario Itza': Itza - Español, Español - Itza. Guatemala: Academia de Lenguas Mayas de Guatemala.

ALMG 2001c Tujaal Choltziij, Vocabulario Sakapulteko: Tujaal Tziij - Kaxtilan Tziij, Kaxtilan Tziij - Tujaal Tziij. Guatemala: Academia de Lenguas Mayas de Guatemala.

ALMG 2001d Qyolb'aal Pqtinmit, Vocabulario Sipakapense: Sipakapense-Español, Español-Sipakapense. Guatemala: Academia de Lenguas Mayas de Guatemala.

ALMG 2001e Ucholaj Ch'a'teem: Vocabulario Achi, Achi-Español, Español - Achi. Guatemala: Academia de Lenguas Mayas de Guatemala.

ALMG 2001f Ak' b'oj payat tzoti' yul ab'xub'al popti'-Actualización lexical idioma maya jakalteko (popti'). Guatemala: Academia de Lenguas Mayas de Guatemala.

ALMG 2001g K'aak' ubee ch'a'teem maya' achi-Actualización lexical idioma maya achi. Guatemala: Academia de Lenguas Mayas de Guatemala.

ALMG 2003a Pujb'il Yol Mam, Vocabulario Mam: Mam-Tyol Mos, Tyol Mos-Mam. Guatemala: Academia de Lenguas Mayas de Guatemala.

ALMG 2003b Jit'il Q'anej Yet Q'anjob'al, Vocabulario Q'anjob'al: Q'anjob'al-Español, Español-Q'anjob'al. Guatemala City: Academia de Lenguas Mayas de Guatemala.ALMG 2003c Lok'ooj Q'orik Poqomam, Vocabulario Poqomam: Poqomam - Kaxlan, Kaxlan - Poqomam. Guatemala: Academia de Lenguas Mayas de Guatemala.

ALMG 2003d Tyolb 'ajil Yol B’a'aj, Vocabulario Tektiteko: Tektiteko-Español, Español-Tektiteko. Guatemala: Academia de Lenguas Mayas de Guatemala.

ALMG 2003e Spaxtial Slolonelal, Vocabulario Chuj: Chuj - Kaxlanh ti', Kaxlanh ti' - Chuj. Guatemala: Academia de Lenguas Mayas de Guatemala.

ALMG 2003f K’ak' taq tzij re k'iche' tzij - Actualización lexical idioma maya k'iche'. Guatemala: Academia de Lenguas Mayas de Guatemala.

ALMG 2004a K'iche' Choltzij, Vocabulario K'iche': K'iche'-Kaxla'n Tzij, Kaxla'n Tzij-K'iche'. Guatemala: Academia de Lenguas Mayas de Guatemala.

1 Note that most of the ALMG dictionaries do not list authors. 
ALMG 2004b Xtusulal Aatin Sa' Q'eqchi', Vocabulario Q'eqchi'. Guatemala: Academia de Lenguas Mayas de Guatemala.

ALMG 2010 Pujb'il yol mam, Diccionario bilingüe mam-español. Guatemala: Academia de Lenguas Mayas de Guatemala.

ALMG 2011 Kaqchikel Choltzij, Kolon Chuqa' K'ak'a Taq Tzij. Guatemala: Comunidad Lingüística Kaqchikel, Academia de Lenguas Mayas de Guatemala.

DQEQ (2005). Diccionario quechua-español-quechua - qheswa-español-qheswa simi taqe. Academia Mayor de la Lengua Quechua de Qosqo - Qheswa Simi Hamut'ana Kurak Suntur. 2nd Edition. Cusco: Academia Mayor de la Lengua Quechua.

SSA2 Suomen sanojen alkuperä: Etymologinen sanakirja. 2, L-P (1995). Ulla-Maija Kulonen, Chief Editor. Suomalaisen Kirjallisuuden Seura, Kotimaisten kielten tutkimuskeskus, Helsinki.

SSA3 Suomen sanojen alkuperä: Etymologinen sanakirja. 3, R-Ö (2000). Ulla-Maija Kulonen, Chief Editor. Suomalaisen Kirjallisuuden Seura, Kotimaisten kielten tutkimuskeskus, Helsinki.

Álgu database

2021 Sámegielaid etymologaš diehtovuođđu / The Etymological Database of the Saami Languages. Helsinki: Research Institute for the Languages of Finland. http://kaino. kotus.fi/algu

Andrés, Domingo, Karen Dakin, José Juan, Leandro López, and Fernando Peñalosa

1996 Diccionario Akateko-Español. Rancho Palos Verdes: Ediciones Yax Te’.

Aulie, H. Wilbur, and de Aulie, Evelyn W.

1978 Diccionario Chol. México, D. F.: Instituto Lingüístico de Verano.

Becerra, Marcos E.

1937 Vocabulario de la lengua chol. Secretaría de Educación Pública, Museo Nacional de México. Anales del Museo Nacional de México, Tomo II, Época 5a. México: Talleres Gráficos de la Nación.

Braudel, Fernand

1979 Civilisation materielle, economie et capitalisme, 15.-18. siecle. Vol. 3: Le temps du monde. Paris: Colin.

Bricker, Victoria, Eleuterio Po'ot Yah, and Ofelia Dzul de Po'ot

1998 A Dictionary of the Maya Language as Spoken in Hocabá, Yucatán. Salt Lake City: University of Utah Press.

Chausidis, Nikos

2012 Mythical Representations of 'Mother Earth' in Pictorial Media. In Archaeology of Mother Earth Sites and Sanctuaries Through the Ages: Rethinking Symbols and Images, Art and Artefacts From History and Prehistory, pp. 5-20, edited by George Terence Meaden. BAR International Series, 2389. Oxford: BAR Publishing.

Christenson, Allen J.

2003 Popol Vuh: The Sacred Book of the Maya: The Great Classic of Central American Spirituality, Translated from the Original Maya Text. Alresford: O Books.

2004 Popol Vuh, Volume II: Literal Poetic Version, Translation and Transcription. Alresford: O Books. 
Cruz Ajcac, Marina, Freddy Gerardo Cotuc, Gaspar Ixcayá, Andrés Hernandez, José Reginaldo Pérez Vail, Ajb'ee Jimenez, Anna Luisa Daigneault, Rodrigo Ranero Echeverría, Gregory D. S. Anderson, and K. David Harrison

2014 Diccionario hablado tz'utujil. K'ulb'il Yol Twitz Paxil / Academia de lenguas mayas de Guatemala, Living Tongues Institute for Endangered Languages, and Comunidad Lingüística Tz’utujil. Version 5.2014. http://www.talkingdictionary.org/tzutujil

Daly, Kathleen N.

2009 Norse Mythology A to Z. Third Edition, revised by Marian Rengel. New York: Chelsea House Publishers.

Damian, Carol

1995 The Virgin of the Andes: Art and Ritual in Colonial Cuzco. Miami Beach: Grassfield Press.

Dean, Carolyn

2010 A Culture of Stone: Inka Perspectives on Rock. Durham: Duke University Press.

Delgaty, Colin C.

1964 Vocabulario Tzotzil de San Andres, Chiapas. Serie de vocabularios indigenas "Mariano Silva y Aceves", No. 10. Mexico: Instituto Lingüístico de Verano \& Dirección General de Asuntos Indígenas de la Secretaría de Educación Pública.

Derks, Sanne, and Meike Heessels

2011 Battered Women Venerating a Vicious Virgin: Reconsidering Marianismo at a Bolivian Pilgrimage Shrine. Culture and Religion 12(3): 303-316. https://doi.org/10.10 80/14755610.2011.605156

Derksen, Rick

2008 Etymological Dictionary of the Slavic Inherited Lexicon. Leiden Indo-European Etymological Dictionary Series, Vol. 4. Leiden \& Boston: Brill.

Derksen, Rick

2015 Etymological Dictionary of the Baltic Inherited Lexicon. Leiden Indo-European Etymological Dictionary Series, Vol. 13. Leiden \& Boston: Brill.

Dobbels, Marcel

2003 Tusq'óorik: Poqomchi' - Kaxlan q'orik, Poqomchi' - Castellano (Diccionario Poqomchi'-Castellano). Guatemala: Programa de Apoyo al Sector Educativo en Guatemala.

Duncan, Barbara, ed.

1986 Gloria in Excelsis: The Virgin and Angels in Viceregal Painting of Peru and Bolivia. New York: Center for Inter-American Relations.

EKI ühendsõnastik

2020 Eesti Keele Instituut, Sõnaveeb 2020. https://sonaveeb.ee

Ferry, Stephen

1999 I Am Rich Potosi: The Mountain That Eats Men. New York: Monacelli Press.

Fratantuono, Lee

2017 A Reading of Lucretius' De Rerum Natura. Lanham: Lexington Books.

Gimbutas, Marija

1991 The Civilization of the Goddess: The World of Old Europe. San Francisco: HarperCollins Publishers.

Goody, Jack

2004 Capitalism and Modernity: The Great Debate. Cambridge: Polity Press. 
Harris, Olivia

2000 To Make the Earth Bear Fruit: Essays on Fertility, Work and Gender in Highland Bolivia. London: Institute of Latin American Studies.

Hofling, Charles Andrew, and Félix Fernando Tesucún

1997 Itzaj Maya-Spanish-English Dictionary / Diccionario maya itzaj-español-inglés. Salt Lake City: University of Utah Press.

Hofling, Charles Andrew

2011 Mopan Maya - Spanish - English Dictionary. Salt Lake City: University of Utah Press.

2014 Lacandon Maya - Spanish - English Dictionary. Salt Lake City: University of Utah Press.

Hopkins, Nicholas

2012 A Dictionary of the Chuj (Mayan) Language as Spoken in San Mateo Ixtatán, Huehuetenango, Guatemala, ca. 1964-65: Chuj-English with Some Spanish Glosses. Tallahassee: Jaguar Tours.

Hopkins, Nicholas A., J. Kathryn Josserand, and Ausencio Cruz Guzmán

2011 A Historical Dictionary of Chol (Mayan): The Lexical Sources from 1789 to 1935. Tallahassee: Jaguar Tours. URL: <http://www.famsi.org/mayawriting/dictionary/ Hull, Kerry hopkins/dictionaryChol.html>

2003 Verbal Art and Performance in Chorti' and Maya Hieroglyphic Writing. Ph.D. Dissertation, University of Texas at Austin.

2016 A Dictionary of Chorti: Mayan - Spanish - English. Salt Lake City: University of Utah Press.

Hurley de Delgaty, Alfa, and Agustín Ruíz Sánchez

1986 Diccionario Tzotzil de San Andrés con Variaciones dialectales. México, D.F.: Instituto Lingüístico de Verano.

Izagirre, Ander

2019 The Mountain That Eats Men. London: Zed Books.

Jackson, Frances L., and Julia Supple

1952 Vocabulario Tojolabal: Breve Coordinación Alphabética de una Lengua Mayance del Estado de Chiapas. México: Instituto Lingüístico de Verano.

Jostad, Patricia M., Leo H. McAvoy, and Daniel McDonald

1996 Native American Land Ethics: Implications for Natural Resource Management. Society \& Natural Resources 9(6):565-581. https://doi.org/10.1080/08941929609380996

Karttunen, Frances

1983 An Analytical Dictionary of Nahuatl. University of Texas Press, Austin.

Kaufman, Terrence

2003 A Preliminary Mayan Etymological Dictionary. With the assistance of John Justeson. http://www.famsi.org/reports/01051/pmed.pdf

2017 Aspects of the Lexicon of Proto-Mayan and Its Earliest Descendants. In The Mayan Languages, edited by Judith Aissen, Nora C. England, and Roberto Zavala, pp. 62111. New York: Routledge / Taylor \& Francis Group.

Keller, Kathryn C., and Plácido Luciano G.

1997 Diccionario Chontal de Tabasco. Serie de vocabularios y diccionarios indígenas "Mariano Silva y Aceves" No. 36. Tucson: Summer Institute of Linguistics. 
Kessel, Juan van

1992 Pachamama, la Virgina: la que creo el mundo y la que fundo el pueblo. Cuadernos de Investigación en Cultura y Tecnología Andina, No. 6. Puno: CIDSA.

Kilarski, Marcin

2007 Algonquian and Indo-European Gender in a Historiographic Perspective. Historiographia Linguistica 34(2):333-349.

Lane, Kris

2019 Potosi: The Silver City That Changed the World. University of California Press.

Larsen, Raymond S.

1955 Vocabulario huasteco del estado de San Luis Potosí. México: Instituto Lingüístico de Verano.

Lastra de Suárez, Yolanda

1989 Otomí De San Andrés Cuexcontitlán, Estado de México. México, D.F.: Archivo de Lenguas Indígenas de México, Colegio de México.

Lemos Barbosa, Pe. Antônio

1956 Curso de tupi antigo: gramática, exerciós, textos. Rio de Janeiro: Livraria São José.

Lewis, Charlton T., and Charles Short

1879 Harpers' Latin Dictionary: A New Latin Dictionary Founded on the Translation of Freund's Latin-German Lexicon Edited by E. A. Andrews. New York, Cincinnati, and Chicago: American Book Company / Oxford: Clarendon Press.

Lindow, John

2001 Norse Mythology: A Guide to the Gods, Heroes, Rituals, and Beliefs. New York: Oxford University Press.

Mallory, J. P., and D. Q. Adams

1997 Encyclopedia of Indo-European Culture. London and Chicago: Fitzroy Dearborn.

2009 The Oxford Introduction to Proto-Indo-European and the Proto-Indo-European World. Oxford: Oxford University Press.

Mares, Courtney

2019 Amazon Synod: Ecological Ritual Performed in Vatican Gardens for Pope's Tree Planting Ceremony. Catholic News Agency Newsletter, October 4, 2019. https:// www.catholicnewsagency.com/news/indigenous-ritual-performed-in-vatican-gardens-for-popes-tree-planting-ceremony-60523

McArthur, Carol, and Richard McArthur

1995 Diccionario pocomam y español. Guatemala: Instituto Lingüístico de Verano.

Moser, Mary B., and Stephen A. Marlett

1998 Seri Dictionary: Earth, Sea, Sky, Time and Weather. Work Papers of the Summer Institute of Linguistics, University of North Dakota, Vol. 42, Article 2. https://commons.und.edu/sil-work-papers/vol42/iss1/2

Nair, Stella

2007 Localizing Sacredness, Difference, and "Yachacuscamcani" in a Colonial Andean Painting. The Art Bulletin, 89(2): 211-238. http://www.jstor.org/stable/25067315

Orchard, Andy

1997 Dictionary of Norse Myth and Legend. London: Cassell.

Pérez Mendoza, Francisco, and Miguel Hernández Mendoza

1996 Diccionario tz’utujil. Antigua, Guatemala: Proyecto Lingüístico Francisco Marroquín. 
Ramírez Pérez, José, Andrés Montejo, and Baltazar Díaz Hurtado

1996 Diccionario del idioma jakalteko. Antigua, Guatemala: Proyecto Lingüístico Francisco Marroquín.

Rogers, Christopher

2010 Comparative Grammar of Xinkan. PhD dissertation, Department of Linguistics, University of Utah.

n.d.a Guazacapan Xinka - English - Spanish Dictionary. Manuscript in the possession of the author.

n.d.b. Jumaytepeque Xinka - English - Spanish Dictionary. Manuscript in the possession of the author.

Ruyán Canú, Déborah, Rafael Coyote Tum, and Jo Ann Munson L.

1991 Diccionario cakchiquel central y español. Guatemala: Instituto Lingüístico de Verano de Centroamérica.

Salles-Reese, Verónica

1997 From Viracocha to the Virgin of Copacabana: Representation of the Sacred at Lake Titicaca. Austin: University of Texas Press.

Seler, Eduard

1887 [Ein Vortrag über die] Namen der in der Dresdener Handschrift abgebildeten Maya-Götter. Zeitschrift für Ethnologie 19: 224-231.

Slocum, Marianna C.

1953 Vocabulario tzeltal-español. México: Instituto Lingüístico de Verano.

Stark Campbell, Sara, Andrea Johnson Peterson, and Filiberto Lorenzo Cruz

1986 Diccionario mixteco de San Juan Colorado. Serie de vocabularios y diccionarios indígenas “Mariano Silva y Aceves” 29. México, D.F.: Instituto Lingüístico de Verano.

Stewart, Cloyd, and Ruth D. Stewart

2000 Diccionario amuzgo de San Pedro Amuzgos, Oaxaca. Serie de vocabularios y diccionarios indígenas "Mariano Silva y Aceves” 44. Coyoacán, D.F.: Instituto lingüístico de Verano.

Stoll, Otto

1896 Die Maya-Sparachen der Pokom-Gruppe. Zweiter Teil: Die Sprache de K'e'kchi-Indianer. Leipzig: K.F. Köhler's Antiquarium.

Streng, Adolf V.

1933 Latinalais-suomalainen sanakirja. Suomalaisen Kirjallisuuden Seuran toimituksia 196. Helsinki: Suomalaisen Kirjallisuuden Seura.

Taube Karl

1992 The Major Gods of Ancient Yucatan. Studies in Pre-Columbian Art and Archaeology, 32. Washington: Dumbarton Oaks Research Library And Collection.

Thomaß, Harald

In Press Con palabras se camina por el paisaje celestial: Cambio y continuidad en la lengua y práctica ritual de los mayas de Yucatán. Proceedings of the 22nd European Maya Conference, Malmö, December 11-15, 2017, edited by Bodil Liljefors-Persson, Harri Kettunen, and Christophe Helmke. Acta Mesoamericana, Vol. 31. München: Verlag Anton Saurwein.

Tola, Miriam

2018 Between Pachamama and Mother Earth: Gender, Political Ontology and the Rights 
of Nature in Contemporary Bolivia. Feminist Review 118(1):25-40. https://doi. org/10.1057/s41305-018-0100-4

Ulrich, E. Matthew, and Rosemary Dixon de Ulrich

1976 Diccionario maya mopan - español, español - maya mopan. Guatemala: Instituto Lingüístico de Verano.

Vásquez Aceituno, Juan Carlos, Ana Luciana Arcón Puzul, and Juan Adolfo Solís Baltazar

2007 Choltziij re Tujaal Tziij - Diccionario bilingüe Sakapulteko. Oxlajuuj Keej Maya' Ajtz'iib'. Antigua, Guatemala: Cholsamaj.

Vicente Méndez, Miguel Angel

2007 Cholaj tzijb’al li Uspanteko - Diccionario Bilingüe Uspanteko-Español. Oxlajuuj Keej Maya' Ajtz'iib'. Antigua, Guatemala: Cholsamaj.

Vuola, Elina

2019 Virgin Mary Across Cultures: Devotion Among Costa Rican Catholic and Finnish Orthodox Women. New York: Routledge.

Wallerstein, Immanuel Maurice

2004 World-Systems Analysis: An Introduction. Durham: Duke University Press.

Welsh, Irvine

1993 Trainspotting. London: Secker \& Warburg.

Yetter, Lynette

2017 Virgin Mary/Pachamama Syncretism: The Divine Feminine in Early-Colonial Copacabana. Western Tributaries, Vol 4.

Zaicz, Gábor

2006 Etimológiai szótár: Magyar szavak és toldalékok eredete. Budapest: Tinta Könyvkiadó. 